\title{
Utopias of the Text: \\ Pre-figurations of the Post-Literary
}

\author{
Benjamin Noys (University of Chichester)
}

\begin{abstract}
:
Utopias of the text are the moments of the emergence of a new and radical concept of the text as overflowing all limits and boundaries. Here these utopias are traced in the writings of Roland Barthes, Jacques Derrida, and Michel Foucault. They often emerge at the margins of these texts, in fragments or boundaries at which the utopia can be glimpsed before disappearing. These utopian moments can be reconstructed as a form of thinking the post-literary and its limits. They can also be traced to the explosion of speech during May 1968 and Maurice Blanchot is a key figure who links together this political moment with the 'neutral' form of writing. This article explores the fading of these utopias of the text alongside this draining of political energies. These processes of critique and waning suggest the inversion of utopias of the text into dystopias of the text. Now the sign or signifier appears dispersed or even insignificant compared to the powers and forces of post-literary domination. In this situation, however, the article suggests, the persistence of the utopias of the text as a critical horizon that can still inform how we grasp the equivocations of our postliterary moment.
\end{abstract}

Keywords: utopia, textuality, Roland Barthes, Jacques Derrida, Michel Foucault, Maurice Blanchot, dystopia.

I want to return to what I will call 'utopias of the text'. This refers to a moment, by now fifty-years old, of the emergence of the text as a utopian moment in theory. In particular, it refers to the May 68 moment of a number of articulations by theorists of what a utopia of the text might be. I find these moments in Roland Barthes, Michel Foucault, and Jacques Derrida. These moments are also to be found in thinkers like Julia Kristeva (1984) and Jacques Lacan (2016), and writer/thinkers like Hélène Cixous (1976) and Philippe Sollers (1983). There was a veritable 'cultural movement' that finds in the text something subversive of 'Western Metaphysics' and 
existing literary culture. ${ }^{\mathrm{i}}$ This is evident in journals such as Tel Quel (ffrench 1995), Screen (Easthope 1988), more 'minor' journals, such as Scription Rouge, and a range of artistic and cultural practices. My aim here is to reconstruct this past moment as one that imagined an equivocal and still troubling form of the 'post-literary'. While references to the 'post-literary' usually engage with new technological forms, from Marshall McLuhan's Gutenberg Galaxy (1962) to recent discussions of Snapchat (Naughton 2017), and often figure the post-literary as the return of the oral, this moment of utopias of the text does something different. Here, to put it simply, it is the moment of writing that comes to exceed and overrun all forms of delimitation. The 'text' or 'writing' escapes from the dominance of the oral and, while inflected by technology, also escapes from any technological determinism (Derrida 1982: 108).

My interest in this moment is not solely antiquarian, but rather an interest in sounding out the current possibilities of the post-literary by a return to this fleeting moment. Obviously, these 'utopias of the text' were articulated with varying degrees of sobriety, from Barthes's bold claims to the caution of Derrida. Also, none of these writers used the term 'utopias', although Barthes's did consider the utopias of Fourier (Barthes 1989: 77-120), while Derrida remained firmly opposed to this word (Derrida 2008: 248-50). Usually this moment has gone under the name of 'poststructuralism' (Belsey 2002), but my choice of 'utopias of the text' is to name something of the radical impulse of this moment that escaped even its prophets. This is evident in the fact that the utopias of the text emerge at the concluding moments of books and essays, or in textual fragments. These are lapidary moments, which are moments of fragmentation or violent condensation, of a sudden fall (Derrida 1988a). They take place at the edge of writing, at the moment of closure, and they seem to stand for a sudden expansion. The text is a big bang, a sudden overflowing or excess, 
in which, to use Derrida's words, 'the text overruns all the limits assigned to it'

(1979: 84). These moments take place at the edge or lip of a discourse. ${ }^{\text {ii }}$

Reflecting retrospectively on this moment, Jacques Derrida remarked on the displacement of speech by a new concept of writing:

This kind of substitution of writing for speech around 1970 deserves its own history and is not limited to Lacan. Ponge told me one day, with a smile, that he was rereading his texts to see whether he had not given in too much to phonocentrism and whether he could replace speech by writing here and there without too much damage. Roger Laporte drew up a list, which I found to be illuminating as it was remorseless, of all the places where, during the same years, our friend Maurice Blanchot, when he republished his old texts in collections, had simply replaced 'speech' by 'writing.' (1998: 61)

I am certainly not writing that history. Instead, I want to take an initial measure of that moment, its relation to its political and cultural context, and how we might reread or return to this moment today. My aim is not to re-establish a lost utopia, but rather to critically assess the fate of this utopian moment as the utopias of the text have overflowed their temporal moment and become engaged in new contexts. This micro-history may, I hope, tell us something of that moment and ours.

\section{Unleashing the Text}

In Barthes the overflowing text overflows all of Barthes' writing from the late 1960s, making itself felt everywhere. At the same time, in Barthes, these texts are often fragmentary in form, as if washed away by the tide of the text or deliberately left porous to the flows of texts through them. It is well-known, to the point of cliché, that Barthes embraces the excess of the text and the utopia of the text as an overcoming of the limits assigned by the author and other functions of containment, such as the 
'work', the signified, plaisir, etc (Barthes 1977: 155-64; Barthes 1975). In 'The Death of the Author', Barthes writes: 'We know now that a text is not a line of words releasing a single "theological" meaning (the "message" of the Author-God) but a multi-dimensional space in which a variety of writings, none of them original, blend and clash' (1977: 146). While repeated to the point of cliché, this remains a statement of the utopia of the text as a moment of freedom beyond the determination of the author. This is the moment of writing as the moment of the post-literary:

In precisely this way literature (it would be better from now on to say writing), by refusing to assign a 'secret', an ultimate meaning, to the text (and to the world as text), liberates what may be called an anti-theological activity, an activity that is truly revolutionary since to refuse to fix meaning is, in the end, to refuse God and his hypostases - reason, science, law. (Barthes 1977: 147)

The text overflows all forms of determination, despite the irony of Barthes returning to text to the reader at the close of his intervention: 'we know that to give writing its future, it is necessary to overthrow the myth: the birth of the reader must be at the cost of the death of the Author' (Barthes 1977: 148).

Barthes's insistence on the notion of 'text' would rupture this strange moment in which everything is abandoned except the reader: 'a text's unity lies not in its origin but in its destination' (Barthes 1977: 148). Even at that point the 'reader' tended towards the 'impersonal', but with the movement 'from work to text' (Barthes 1977: 155-64), we would fully enter the utopia of the text. In fact, in his later consideration of textual utopias, Sade, Fourier, Loyola, Barthes would suggest that the text is beyond utopia: the text releases a happiness, unglues the text from guarantees, and displaces utopia (1989: 9). At this limit point, the utopia as "noplace', or as the biopolitical constructions of Sade, Fourier, and Loyola, is constructed through the text but the text overflows even this delimitation. Fourier 
predicted that with the realisation of utopia the seas would transform into lemonade (Barthes 1989: 117); in Barthes these lemonade seas become the seas of the signifier, without end or limit.

In another moment of the displacement of the author, at the conclusion to 'What is an Author?' (1969), Foucault makes a prediction that echoes the conclusion of his The Order of Things, in which 'one can certainly wager that man would be erased, like a face drawn in sand at the edge of the sea' (1974: 387). If 'man' is to be erased then so too is that other figure of man, the author. A new regime is emerging in which discourses would 'develop in the anonymity of a murmur' (1984: 119) and a new indifference would reign, as Foucault paraphrases Beckett's Texts for Nothing (Beckett 1986: 78), without attribution appropriately, 'What difference does it make who is speaking?' (Foucault 1974: 120).

There is restraint here. Foucault suggests that we are undergoing a change in which 'fiction and its polysemous texts will once again function according to another mode, but still with a system of constraint' (1984: 119). The end of the era of the subject, and so of the author, would not usher in an unrestrained new age, but rather a new 'system of constraint'. But then what utopia has been without its own particular detailed plan and rules of constraint? Thomas More's Utopia, to use other terms from Foucault, is a society that is biopolitical and a 'society of surveillance'. In true Panoptic style, More's Utopia will be a place where 'Everyone has his eye on you, so you're practically forced to get on with your job, and make some proper use of your spare time' (1965: 84). Although we should also note that More's Utopia is also a particular and peculiar textual utopia, a machine of writing that tries to engender educative effects (Abensour 2017). Similarly, the Fourierian Phalanstery, dedicated to pleasure, is a biopolitical institution, with its regulations and structure. So, while 
Foucault is more cautious than Barthes, and he would soon shift his work away into the historical inquiries into biopolitics that dominate his reception today, at this moment a utopia of the text makes a fleeting emergence in Foucault's work.

At the end of the introduction to The Archaeology of Knowledge Foucault announces:

I am no doubt not the only one who writes in order to have no face. Do not ask who I am and do not ask me to remain the same: leave it to our bureaucrats and our police to see that our papers are in order. At least spare us their morality when we write. (2002: 19).

In an anonymous interview, titled 'The Masked Philosopher', Foucault makes another suggestion:

I shall propose a game: that of the 'year without a name.' For a year books would be published without their authors' names. The critics would have to cope with a mass of entirely anonymous books. But, now I come to think of it, it's possible they would have nothing to do: all the authors would wait until the following year before publishing their books ... (1988: 324)

Of course, it is an historical irony that Foucault is regularly reported as the most cited scholar in the social sciences and humanities. Anonymity, disappearance, the republic of letters as a republic without authors, these are further signs of the utopia of the text that take their place alongside Foucault's utopian suggestion of a future dominated by 'sexual acts' rather than 'sexual identities' (Foucault 1988: 286-303).

Of all the thinkers I will discuss, Derrida is, as I have remarked, the most sober about the utopias of the text. The development of writing as a form not beholden to the metaphysical opposition of speech to writing, in the form of archiwriting or the trace, was not the announcement of a new age. In 'Structure, Sign, and Play', we are offered an apparent choice between a 'saddened, negative, nostalgic, 
[and] guilty' thought of the absent origin or 'the joyous affirmation of the play of the world and of the innocence of becoming, the affirmation of a world of signs without fault, without truth, and without origin' (1978: 292), but only for Derrida to carefully add 'I do not believe that today there is any question of choosing' (1978: 293; italics in original). If we were to believe that we had entered the time of the 'free play of the signifier', as many did, then we would be wrong; the Nietzschean announcement of the breaking of the tablets of the law cannot be separated from the nostalgic and guilty.

And yet, the essay concludes on another note. Derrida is not immune to that 'apocalyptic tone' he would later so astutely analyse (Derrida 1984). There are those who 'turn their eyes away when faced by the as yet unameable which is producing itself and which can do so, as is necessary when a birth is in the offing, only under the sign of the nonspecies, in the formless, mute, infant, and terrifying form of monstrosity' (1978: 293). Slouching towards Bethlehem is the 'rough beast' of différance (Yeats 1994: 235). This 'rough beast' emerges at the end of another Derrida text: 'Such a différance would at once, again, give us to think a writing without presence and without absence, without history, without cause, without archia, without telos, a writing that absolutely upsets all dialectics, all theology, all teleology, all ontology' (1982: 67). The promise of différance does seem to be of the utopia of the text we cannot choose.

At the end of 'The Ends of Man' Derrida asks, 'Is there an economy of the eve?' (1982: 136). Of course, in later work, Derrida would stress the binding and stricture of the economy (Derrida 1986), as well as the moment of 'aneconomy' that emerges through and with economy (Derrida 1992). While there is restraint and restriction here the tension between these two moment threatens to split into an 
antinomy, between the text as monstrous future or as 'totally Other' (Derrida 1995), and the text as simply the system of infinite differences (Badiou 2001: 25). Here the utopia of the text risks or even courts banality, while holding on to what Badiou calls 'a point of flight' that results from 'a dispositif of acephalic writing' (2009: 545; italics in original). ${ }^{\mathrm{iii}}$ This results, according to Badiou, in a split 'between the most overtly literary prose and the harshest philosophical conceptuality, whose emblem is the Genet/Hegel pairing in Glas' (2009: 545).

This threatened or actual split, the tension of an economy that tries to bind or restrict the overflowing text while also permitting that overflowing, structures the moment of utopias of the text. These utopias of the text should not be mistaken for utopias of language; the rupture of writing is, as Derrida puts it, the rupture with the 'logocentrism' of language (Derrida 1974). These are utopias of the text, in Barthes (1974: 155-64), of discourse, in Foucault (2002), and of the trace, in Derrida (2016: 25). Here the utopias of the text touch on the 'post-literary' as something that cannot be contained by language, while at the same time not simply coinciding with the oral, the technological, or some 'other' of writing. Yet, as I have suggested, they remain highly unstable, likely to tip over into the banality of the world as it is. These announcements, so disturbing at that moment, and at times since, may simply become consonant with 'culture' or simply with the distributed world as we find it or things as they are. ${ }^{\text {iv }}$ I will return to this problem.

\section{'The streets have awakened'}

The Barthesian 'liberation of the signifier' (Barthes 1973: 9), and all the other utopias of the text, found their roots and confirmation in the liberation of language 
occasioned by May '68 and after. Writing in 1968, Barthes (1986: 140) had argued that 'The students' speech so completely overflowed, pouring out everywhere, written everywhere, that one might define superficially - but also, perhaps, essentially - the university revolt as a Taking of Speech (as we say Taking of the Bastille)' (see also de Certeau 1997: 11). Now speech and writing emerge as public, anonymous, and everywhere, notably in the post-literary form of slogans and graffiti. It is in this moment and in its wake that the utopias of the text gained a radical effect, a promise that is not only 'textual' but also political. The old dreams of the late nineteenth-century avant-garde - Lautreamont's 'plagiarism is necessary. It is implied in the idea of progress' (1988: 274); Rimbaud's 'logical revolts' (2009: 309); Mallarmé's 'book' 'glittering like a cut diamond' (Rancière 2011: 79) - are realised in the streets. The streets, as Maurice Blanchot realized, being the site of this utopia: 'the streets have awakened: they speak' (2010: 91). The street is the site of the 'sovereign word', the place to be free and 'to make something happen' (2010: 91).

It is Blanchot's texts and communiques from May ' 68 that make clear the link between the utopias of the text and the forms of post- and para-literary writing that emerged at the moment. In a series of writings for the Student-Writer Action Committee and the review Comité from that year, Blanchot explores a new mode of writing:

The book has not disappeared; this must be acknowledged. Nonetheless, we can say that everything that in the history of our culture, and in history tout court, incessantly destines writing not for the book but for the absence of the book has continued to announce the upheaval by preparing for it. There will still be books and, what's worse, beautiful books. But mural writing, this mode that is neither inscription nor enunciation, the tracts that are hastily distributed in the streets and are the manifestation of the haste of the streets, the posters that do not need to be read but are like a challenge to every law, words of disorder, the speech outside discourse that marks our steps, political cries - and bulletins by the dozen, like this one, everything that disturbs, calls, threatens, and finally questions without expecting an answer, without resting in certainty, never will 
we enclose it in a book, which, even when open, tends towards closure, a refined form of oppression. (2010: 94-5)

Already, we see the emergence of a series of forms that abandon the book: murals, tracts, posters, political cries, bulletins, and we could add slogans (Mieszkowski 2016) and graffiti - in the words of Norman Mailer, 'Your presence on their Presence ... hanging your alias on their scene' (quoted in Hebdige 1987: 3).

The utopias of writing, announced often in books, but also in fragmentary books, at the edges of texts and in 'books' composed of other texts (as in the case of Derrida's works), emerged out of '[t]racts, posters, bulletins, words of the streets, infinite words', which '[1]ike words on the wall, ... are written in insecurity, received under threat; they carry the danger themselves and then pass with the passerby who transmits, loses, or forgets them' (Blanchot 2010: 95). Here the utopias of the text are linked to the post-literary but, as we have seen, in a series of texts or modes that do not settle easily into the oppositions of speech/writing or text/image. This may well be why, in the graffiti of King Mob of the late 1960s, we see the reference to William Blake, as another 'political' figure of the post-literary 'composite art' (Cooper 2017: 133-5). The political and the rupture of the boundaries of language, of the literary and the post-literary, are what form these 'utopias of the text'.

Fredric Jameson has written of the 1960s as the experience of 'the adventure of the sign' (1984: 194-201), an adventure I have partially retraced here. For Jameson this adventure is not merely an idealist retreat into the sign or signifier, but rather an engaged process of cultural revolution, even if that revolution then encounters its own limit:

The 60s were in that sense an immense and inflationary issuing of superstructural credit; a universal abandonment of the referential gold standard; an extraordinary printing up of ever more devalued signifiers. 
With the end of the 60s, with the world economic crisis, all the old infrastructural bills then slowly come due once more; and the 80 s will be characterized by an effort, on a world scale, to proletarianize all those unbound social forces which gave the 60s their energy, by an extension of class struggle, in other words, into the farthest reaches of the globe as well as the most minute configurations of local institutions (such as the university system). (1984: 208)

For Jameson, the 1980s would be characterised by a 'proletarianisation' of radical forces. Today, we might be tempted to speak of the atomisation of those forces. The projects of textual subversion appear to have definitively come to an end, eclipsed in our moment of crisis and capitalist domination.

\section{Dystopias of the Text}

The moment of May '68 seemed to provide the energy for the utopias of the text; what, then, might account for their fading? We could obviously suggest that the fading of the utopias of the text has something to do with the fading of May ' 68 , now fifty years past. In fact, the link between May '68 and the emergence of writing 'around 1970' has often been charged negatively. Far from being utopias of the text, these utopias, like so many others, have been easily flipped into dystopias of the text. This flipping takes a number of overlapping forms, as the critical charges against these utopias of the text pile up: recuperation, obscuring, mimicry, and obsolescence. While I will tease these apart, we should easily seem how they also run together.

The first is recuperation - that the utopias of the text absorb the utopias of the street and re-package them as utopias of the classroom. They are 'symptoms of political defeat' (Eagleton 1996: 19; italics in original). Reversing Blanchot's endorsement of his own theoretical work as realised in May '68, now this 
'realisation' becomes a taming of insurgent energies into respectable forms. Iain Sinclair has noted, in terms of the material culture of the counter-culture of the 1960s, the lineaments of this process:

It takes 20 years for stapled samizdat effusions that everybody has and nobody wants to become prized rarities that nobody has and everybody wants. Time enough for the original prophets and gladiators to die. Commodity capitalists will already be stuffing first editions of these tattered hate sheets into storage jars as cheap futures, no-risk investments. (Sinclair 1992)

The utopias of the text would be something different, a strange preservation of energies, a plastic bagging, which renders a political frisson at the cost of political

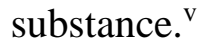

This charge, of utopias of the text as symptoms of political defeat and effects of recuperation, easily slides into the next charge: utopias of the text obscure political processes. Donna Haraway, in her 'Cyborg Manifesto', neatly summarised the dystopian charge against the utopias of the text: 'Textualization of everything in poststructuralist, postmodernist theory has been damned by Marxists and socialistfeminists for its utopian disregard for the lived relations of domination that ground the "play" of arbitrary reading' (Haraway 2016: 12). The 'utopian disregard' of the political renders these utopias as dystopias of play that are erected as sites of privilege over the constraints of material suffering.

Even worse is the next charge: one of mimicry. Not only do the utopias of the text disguise power relation that also forms a mirror of those relations, not so much a 'mirror of production', as Baudrillard (1975) put it, but a 'mirror of speculation'. While the utopias of the text might have emerged around 1970, shortly after we would witness the beginnings of the dominance of speculative finance and 'fictitious capital', with all its abstract instruments of colonising the future (Durand 2017). This 
is seen as no coincidence, with the free play of the signifier as predictive or mimicking the floating world of speculative finance capital (Goux 1988: 23). Here the dystopia of mobile and deadly financial abstractions is celebrated as the utopia of textual play (Goux 1990).

The final turn of the screw is obsolescence. Now, the utopias of the text appear not so much as malign as exhausted. The slogans fade, as have the political slogans that imbued this moment with energy. Iain Sinclair writes, in 1992, of a visit to the Stonebridge Estate in Haggerston:

Rivulets from burst pipes, clinking lianas, muted the defiant calligraphy that defaced these walls. Monster slogans in braille aimed at the wilfully blind. Demands. Complaints. Curses. This was not the work of a coven of Class War anarchists but the frantic message-in-a-bottle charter of humans at the end of their tether: marooned exiles who had nothing left beyond a collaboration with the masonry that held them prisoner. The message the dwellings tapped out was simple: 'tear us down.' The white lettering was a suicide note. (Sinclair 1992)

Whether we trust Sinclair's reading, here slogans are transformed from moments of political energy to desperate expression of exhaustion.

Utopias of the text exist not only on the cusp of financialisation but also on the linked cusp of the 'long downturn' (Brenner 2006), which, as Sarah Brouillette (2017) has forcefully argued, has undermined the conditions for a society centred on the literary. The postwar period of Fordism and national development was the time of 'waged labor, public schooling, and mass literacy' and, Brouillette argues, '[m]any things that are necessary to the development of the specifically literary disposition are decreasingly available' (2017). ${ }^{\text {vi }}$ In this situation, 'Students report that literary books are hard to relate to; pressure on teachers to cover subjects with clear parameters and learning outcomes has grown' (Brouillette 2017). Mark Fisher has characterised this condition as not so much one of the post-literary, but of post-lexia or of the post- 
literate (2009: 25). Fisher cites Deleuze and Guattari: 'Writing has never been capitalism's thing. Capitalism is profoundly illiterate' (Fisher 2009: 25; Deleuze and Guattari 1983: 240). The emergence of the post-literary would not signal the triumph of the technological, the return of the oral, or some other 'autonomous' development, but the crisis of a set of conditions that have now slumped into the age of austerity and resurgent neo-liberalism (Mirowski 2014). The loss of appeal of the utopias of the text would not be some sign of intellectual fashion or intellectual weakness, but rather a slippage between moment and conditions. If financialisation, which emerges as the response to the long downturn, is the sign of the 'autumn of the system' (Clover 2011), then the utopias of the text would have been the signs of late summer. The moment of 'when luxuriously / Spring's honied cud of youthful thought he loves / To ruminate, and by such dreaming high / Is nearest unto heaven' passes into the moment 'to let fair things / Pass by unheeded as a threshold brook' (Keats 1988: 232).

Even the moment of political graffiti in our present moment seems to inhabit a certain exhaustion. The Invisible Committee, in To Our Friends, note that 'the epoch has even begun to secrete its own platitudes, like that All Cops Are Bastards (ACAB) which a strange internationale emblazons on the rough walls of cities, from Cairo to Istanbul, and Rome to Paris or Rio, with every thrust of revolt' (2014: 12). The utopias of the text, under this combined assault, may have faded or even been rendered obsolete, but they also encode something of a past not realised. The utopian element today emerges out of this uncanny failure, out of this obsolescence, which might not just signal the end of utopia but a situation in which something remains disruptive as unthought. We might be reminded of Adorno's claim in relation to 
philosophy: 'Philosophy, which once seemed obsolete, lives on because this moment to realize it was missed' (1973: 3).

\section{Conclusion}

Jorge Luis Borges writes that 'the universe (which others call the Library) is composed of an indefinite and perhaps infinite number of hexagonal galleries, with vast air shafts between them, surrounded by very low railings', in his 1941 story 'The Library of Babel' (1970: 78). Borges is usually allied with the celebration of the utopia of text (Derrida 1993: 84-5; Foucault 1974: xv), but his writings suggest something of the uncanny situation of those utopias today. In 'The Library of Babel' the universe as library is filled with books that may be nonsensical, that fold onto each other, and which lead to proliferating heresies. One group of the 'impious' speak of the 'feverish Library whose chance volumes are constantly in danger of changing into others and affirm, negate and confuse everything like a delirious divinity' (1970: 84). This notion of a 'feverish library' is reminiscent of Barthes's suggestion the text take as its name 'Legion', 'for we are many', and that the 'plural if Evil' for our monotheistic cultures (Barthes 1977: 160). The coinciding of the library with the universe echoes the architecture of the 'imaginary prisons' of Piranesi. In an essay on Don Quixote, discussing the effect of mise en abyme, Borges concludes: 'In 1833, Carlyle observed that the history of the universe is an infinite sacred book that all men write and read and try to understand, and in which they are also written' (1970: 231). Here the active and productive utopia of the text becomes a passive site of inscription and writing that determines our fate as mere puppets of the text. 
This appears a melancholy solution, alongside Adorno's suggestion of the missed moment, and strangely antithetical to the joyous moment of the utopias of the text, if not to their later fate. Certainly, I am not interested in inhabiting a melancholic tone, although also not in returning to a joyous affirmative tone (Noys 2010). Instead, I want to conclude on a note that suggests that these utopias of the text still matter. To return to Donna Haraway's recognition of doubt about the effectivity of utopias of the text in related footnote she registers a certain pertinence. Our shifting political moment, she is writing in 1985, is one of 'technobabble', 'the language of spliced substantives' of corporate naming (Haraway 2016: 70, n.5). In this situation: 'If we are imprisoned by language, then escape from that prison-house requires language poets, a kind of cultural restriction enzyme to cut the code; cyborg heteroglossia is one form of radical cultural politics' (Haraway 2016: 70, n.5). Haraway's suggestion is that language might be cure as well as poison, to echo Derrida's analysis of writing as pharmakon (Derrida 1993: 95-117). ${ }^{\mathrm{vii}}$

While Paolo Virno may overstate the contemporary situation as a 'productive process based directly upon the power of verbal thought' (2008: 11), certainly language and writing continue to matter as one of the forms in which the abstractions of the present can be rendered. As both the early and late Marx insisted, there is a 'commodity language', which is 'the language our possessions use together' (Marx 1975 276; see also Marx 1991: 143-4; Hamacher 2008; Derrida 1994: 157-8). This 'language', the language of value, is a 'language' that is inextricably bound to the 'material' (Godden and Szalay 2014). In this case, as Werner Hamacher (2008) suggested, 'language' speaks not only for the commodity but also potentially in excess of this value of exchange. In this sense, the utopias of the text still carry a utopian and 'post-literary' charge in their capacity to challenge and rupture this 
language of 'spliced substantives' and floating value (Noys 2017). Melancholia or affirmation, dystopia or utopia, might then be rendered obsolete, but in a fashion that our present has not exhausted. If the streets continue to awaken only then to return to sleep, perhaps the dreams of streets remain a language that we might decrypt today.

\section{References}

Abensour, Miguel (2017), Utopia from Thomas More to Walter Benjamin, trans. Raymond N. MacKenzie, Minneapolis: Univocal.

Adorno, Theodor (1973), Negative Dialectics, trans. E. B. Ashton, London: Routledge \& Kegan Paul.

Badiou, Alain (2001 [1993]), Ethics: An Essay on the Understanding of Evil, trans. Peter Hallward, London: Verso.

Badiou, Alain (2009 [2006]), Logics of Worlds: Being and Event II, trans. Alberto Toscano, London: Continuum.

Barthes, Roland (1973 [1957]), Mythologies, trans. Annette Lavers, London: Granada.

Barthes, Roland (1975 [1973]), The Pleasure of the Text, trans. Richard Miller, New York: Hill \& Wang.

Barthes, Roland (1977), Image Music Text, trans. Stephen Heath, London: Fontana.

Roland Barthes (1986 [1984]), The Rustle of Language, trans. Richard Howard, Berkeley: University of California Press.

Barthes, Roland (1989 [1971]), Sade, Fourier, Loyola, trans. Richard Miller, Berkeley and Los Angeles: University of California Press. 
Baudrillard, Jean (1975 [1973]), The Mirror of Production, trans. and intro. Mark Poster, St Louis, MO: Telos Press.

Baudrillard, Jean (1999 [1986]), America, trans. Chris Turner, London and New York: Verso.

Beckett, Samuel (1986), Collected Shorter Prose 1945-1980, London: John Calder.

Belsey, Catherine (1980), Critical Practice, London: Routledge.

Belsey, Catherine (2002), Poststructuralism: A Very Short Introduction, Oxford: Oxford University Press.

Blanchot, Maurice (2010), Political Writings, 1953-1993, trans. and intro. Zakir Paul, New York: Fordham University Press.

Borges, Jorge Luis (1970), Labyrinths, trans. Donald E. Yates and James E. Irby, Harmondsworth: Penguin.

Brenner, Robert (2006), The Economics of Global Turbulence: The Advanced Capitalist Economies from Long Boom to Long Downturn, 1945-2005, London: Verso.

Brouillette, Sarah (2017), 'On the African Literary Hustle', blind field, 14 August $2017<$ https://blindfieldjournal.com/2017/08/14/on-the-african-literary-

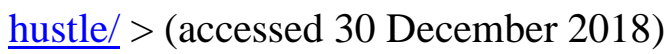

Cixous, Hélène (1976 [1975]), 'The Laugh of the Medusa', trans. Keith Cohen and Paula Cohen, Signs 1: 4, 875-93. http://www.jstor.org/stable/3173239

Clover, Joshua (2011), 'Autumn of the System: Poetry and Financial Capital', Journal of Narrative Theory, 41: 1, 34-52.

Cooper, Sam (2017), The Situationist International in Britain: Modernism, Surrealism, and the Avant-Gardes, London: Routledge. 
de Certeau, Michel (1997 [1994]), The Capture of Speech \& Other Political Writings, intro. Luce Giard, trans. and afterword Tom Conley, Minneapolis: University of Minnesota Press.

Deleuze, Gilles and Félix Guattari (1983 [1972]), Anti-Oedipus, trans. Mark Seem et al, Minneapolis: University of Minnesota Press.

Derrida, Jacques (1974 [1967]), Of Grammatology, trans. Gayatri Chakravorty Spivak, Baltimore: The Johns Hopkins University Press.

Derrida, Jacques (1978 [1967]), Writing and Difference, trans. Alan Bass (Chicago: University of Chicago Press).

Derrida, Jacques (1979), 'Living On: Borderlines', in Deconstruction and Criticism, Harold Bloom et al, New York: Continuum, pp. 75-176.

Derrida, Jacques (1980), 'The Law of Genre’, Critical Inquiry, 7: 1, 55-81.

Derrida, Jacques (1982 [1972]), Margins of Philosophy, trans. Alan Bass, Brighton: The Harvester Press.

Derrida, Jacques (1984 [1983]), 'Of an Apocalyptic Tone Recently Adopted in Philosophy', Oxford Literary Review, 6: 2, 3-37.

Derrida, Jacques (1986 [1974]), Glas, trans. Richard Rand and John P. Leavey, Lincoln: University of Nebraska Press.

Derrida, Jacques (1988a), 'My Chances/Mes Chances: A Rendezvous with Some Epicurean Stereophonies', in Joseph H. Smith and William Kerrigan (eds), Taking Chances: Derrida, Psychoanalysis, and Literature, Baltimore: The Johns Hopkins University Press, pp.1-32.

Derrida, Jacques (1988b), 'Choreographies', trans. Avital Ronell, in The Ear of the Other, ed. Christie McDonald, Lincoln, NE: University of Nebraska Press, pp.163-185. 
Derrida, Jacques (1989), 'Some Statements and Truisms about Neologisms, Newisms, Postisms, Parasitisms, and other small Seismisms', in David Carroll (ed.), The States of Theory, New York: Columbia University Press, pp. 63-94 Derrida, Jacques (1992 [1991]), Given Time 1: Counterfeit Money, trans. Peggy Kamuf, Chicago: University of Chicago Press.

Derrida, Jacques (1993 [1972]), Dissemination, trans. and intro, Barbara Johnson, London: The Athlone Press.

Derrida, Jacques (1994 [1993]), Specters of Marx: The State of the Debt, the Work of Mourning, and the New International, trans. Peggy Kamuf, London: Routledge.

Derrida, Jacques (1995 [1992]), The Gift of Death, trans. David Wills, Chicago: University of Chicago Press.

Derrida, Jacques (1998 [1996]), Resistances of Psychoanalysis, trans. Peggy Kamuf et al, Stanford, CA: Stanford University Press.

Derrida, Jacques (2008 [2002]), 'Marx \& Sons', in Ghostly Demarcations, ed. Michael Sprinker, London and New York: Verso, pp. 213-69.

Derrida, Jacques (2016 [1987]), Cinders, Minneapolis and London: University of Minnesota Press.

Durand, Cédric (2017), Fictitious Capital: How Finance Is Appropriating Our Future, trans. David Broder, London: Verso.

Eagleton, Terry (1996), The Illusions of Postmodernism, Oxford: Blackwell. Easthope, Antony (1988), British Post-structuralism since 1968, London: Routledge. Easthope, Antony (1991), Literary into Cultural Studies, London: Routledge. ffrench, Patrick (1995), The Time of Theory: A History of Tel Quel (1960-1983), Oxford: Clarendon Press. 
Fisher, Mark (2009), Capitalist Realism, Winchester: Zero Books.

Foucault, Michel (1974 [1966]), The Order of Things (London: Routledge/Tavistock).

Foucault, Michel (1984 [1969]), 'What is an Author?', in The Foucault Reader, ed. Paul Rabinow, London: Penguin, pp. 101-20.

Foucault, Michel (1988), 'The Masked Philosopher', in Politics, Philosophy, Culture: Interviews and Other Writings, 1977-1984, ed. Lawrence D. Kritzman, London: Routledge, pp. 323-30.

Foucault, Michel (2002 [1969]), The Archaeology of Knowledge, trans. A. M. Sheridan Smith, London: Routledge.

Godden, Richard and Michael Szalay (2014), 'The Bodies in the Bubble: David Foster Wallace's The Pale King', Textual Practice, 28: 7, 1273-1322.

Goux, Jean-Joseph (1988), 'Banking on Signs', trans. Thomas DiPiero, Diacritics, 18: $2,15-25$.

Goux, Jean-Joseph (1990), 'General Economics and Postmodern Capitalism', trans. Kathryn Ascheim and Rhonda Garelick, Yale French Studies 78, 'On Bataille', 206-24.

Habermas, Jürgen (1989), 'The Public Sphere: An Encyclopedia Article', in Critical Theory and Society: A Reader, in Stephen Eric Bronner and Douglas MacKay Kellner (eds), New York and London: Routledge, pp. 136-42.

Habermas, Jürgen (1991 [1962]), The Structural Transformation of the Public Sphere, trans. Thomas Burger, Cambridge, MA: The MIT Press.

Hamacher, Werner (2008), 'Lingua Amissa: The Messianism of CommodityLanguage and Derrida's Specters of Marx', in Jacques Derrida et al, Ghostly 
Demarcations: A Symposium on Jacques Derrida's Specters of Marx, ed. and intro. Mike Sprinker, London: Verso, pp. 168-212.

Haraway, Donna J. (2016), Manifestly Haraway, Minneapolis: University of Minnesota Press.

Hebdige, Dick (1987), Subculture: The Meaning of Style, London: Routledge.

Invisible Committee, The (2015 [2014]), To Our Friends, trans. Robert Hurley, South Pasadena, CA: Semiotext(e).

Irigaray, Luce (1985 [1997]), This Sex Which is Not One, trans. Catherine Porter with Carolyn Burke, New York: Cornell University.

Jameson, Fredric (1984), 'Periodizing the 60s', 'The 60's without Apology', Social Text, 9/10, $178-209$.

Jameson, Fredric (1994), The Seeds of Time, New York: Columbia University Press.

Keats, John (1988), Complete Poems, London: Penguin.

Kristeva, Julia (1984 [1974]), Revolution in Poetic Language, trans. Margaret Waller, intro. Leon S. Roudiez, New York: Columbia University Press.

Lacan, Jacques (2016 [2005]), The Sinthome: The Seminar of Jacques Lacan, Book XXIII, ed. Jacques Alain Miller, trans. A. R. Price, Cambridge: Polity.

Lautréamont, Comte de (1978 [1868-69]), Maldoror and Poems, trans. Paul Knight, London: Penguin.

Marx, Karl (1975 [1833-34), Early Writings, intro. Lucio Colletti, trans. Rodney Livingstone and Gregor Benton, London: Penguin.

Marx, Karl (1991 [1867]), Capital vol. 1, intro. Ernest Mandel, trans. Ben Fowkes, Harmondsworth: Penguin.

McLuhan, Marshall, (1962), The Gutenberg Galaxy, Toronto: University of Toronto Press. 
Mieszkowski, Jan (2016), 'What's in a Slogan?', Mediations, 29: 2 (Spring), 149-60 $<$ www.mediationsjournal.org/articles/whats-in-a-slogan $>$ (accessed 30 December 2018)

Mirowski, Philip (2014), Never Let a Serious Crisis Go to Waste: How Neoliberalism Survived the Financial Meltdown, London: Verso.

More, Thomas (1965 [1516]), Utopia, trans. and intro. Paul Turner, London: Penguin.

Mulhern, Francis (2016), Figures of Catastrophe: The Condition of Culture Novel, London: Verso.

Naughton, John (2017), 'Is Snapchat the sign of a post-literary future?', The Guardian, $\quad 12 \quad$ March $\quad 2017 \quad<$ https://www.theguardian.com/commentisfree/2017/mar/12/snapchat-sign-ofpost-literary-future $>$ (accessed 30 December 2018).

Negt, Oskar, and Alexander Kluge (2016), Public Sphere of Experience: Analysis of the Bourgeois and Proletarian Public Sphere, London: Verso.

Noys, Benjamin (2010), The Persistence of the Negative: A Critique of Contemporary Continental Theory, Edinburgh: Edinburgh University Press.

Noys, Benjamin (2017), 'Hex Position: The Poetics and Politics of the Hex in Contemporary British Experimental Poetry', in Anthony Iles et al. (eds), Look at Hazards, Look at Losses, London: Mute, pp.133-49.

Noys, Benjamin (2018a), 'The Peculiarities of English Culture: A Review of Figures of Catastrophe: The Condition of Culture Novel by Francis Mulhern', Historical Materialism (February 2018) < DOI: 10.1163/1569206x12341556. >. 
Noys, Benjamin (2018b), “Freudful Mistakes": On Forgetting and On Forgetting Psychoanalysis', Problemi, 2, 279-96.

Rancière, Jacques (2011 [1996]), Mallarmé: The Politics of the Siren, trans. Steve Corcoran, London: Continuum.

Rimbaud, Arthur (2009), Collected Poems, trans. Martin Sorrell, Oxford: Oxford University Press.

Sinclair, Iain (1992), 'Lady Thatcher's Bastards', London Review of Books 14: 4, 56. Retrieved from https://www.lrb.co.uk/v14/n04/iain-sinclair/lady-thatchersbastards.

Smith, Jason (2009), 'Jacques Derrida, “Crypto-Communist?”, in Jacques Bidet and Stathis Kouvelakis (eds.), Critical Companion to Contemporary Marxism (Chicago: Haymarket Books, 2009), pp. 625-45.

Sollers, Philippe (1983 [1976]), Writing and the Experience of Limits, ed. David Hayman, trans. Philip Barnard, New York: Columbia University Press.

Virno, Paolo (2008), Multitude: Between Innovation and Negation, trans. Isabella Bertoletti, James Cascaito, and Andrea Casson, Los Angeles, CA: Semiotext(e).

Yeats, W. B. (1994), The Poems, ed. Daniel Albright, London: Everyman.

\section{Notes}

While this is a French phenomenon, we could also consider a milder utopia articulated in the form of speech and the public sphere by Jürgen Habermas during the 1960s (Habermas 1989; Habermas 1991; Negt and Kluge 2016). Fredric Jameson notes: 
That the paradigm, although obviously French in its references, is not merely local can be judged from an analogous mutation of the classical Frankfurt School via problems of communication, in the work of Habermas; or by the current revival of pragmatism in the work of Richard Rorty, which has a home- grown American 2post-structuralist" feeling to it (Peirce after all having largely preceded and outclassed Saussure. (1984: 187)

ii This would also open consider of the gendering of the text, via the thinking of the lip or edge and through 'écriture féminine' (Irigaray 1985; Cixous 1976; Derrida 1980; Derrida 1988b).

iii Badiou will mathematically formalise Derrida's procedure as the pursuit of the 'inexistent' (2009: 545).

iv Framed in a more critical fashion this is also the moment of cultural studies, which in part forms around the challenge to expand or transgress the literary through 'signifying practices' (Hebdige 1987; Easthope 1991; Belsey 1980).

$\checkmark \quad$ It is worth noting that Derrida expressed considerable political doubts about the 'spontaneism' of May '68, and often in impeccably Leninist terms (Smith 2009). vi The consideration of the class tensions of the moment of social democracy and its crisis can be found in Francis Mulhern's ingenious mapping of 'condition of culture' novels in Britain across the twentieth and twenty-first century (Mulhern 2016: see also Noys 2018a).

vii On these paradoxical possibilities of language in our anti-language moment see Noys 2018b. 